\title{
Pengaruh Suasana Toko Dan Diskon Terhadap Pembelian Impulsif Pada Matahari Department StorePasar Besar Malang
}

\author{
Jelita Virliana Sandra1, Widiya Dewi Anjaningrum,, \\ Institut Teknologi dan Bisnis Asia Malang, Indonesia ${ }^{1,2}$
}

$凶$ Corresponding Author:

\section{Nama Penulis: Jelita Virliana Sandra}

E-mail: jelitavirliana37@gmail.com

\begin{abstract}
In line with the increasing demand for fashion in Indonesia, this phenomenon is exploited by businessman, especially the retail business. Many retail business are still standingand surviving to this day. They are Matahari Department Store Pasar Besar Malang has a strategy in maintaining its business by having knowledge of its consumer shopping behavior. The purposes of this study was to determine the effect of store atmosphere and discount on impulse buying at Matahari Department Store Pasar Besar Malang. This research is an explanatory research with multiple linear regression analysis techniques. The population in this study were all unknown consumers of Matahari Department Store Pasar Besar Malang. The sampling technique used was accidentalpurposive sampling technique with 100 sample respondents. The result of multiple linear regression analysis found that store atmosphere hasa positive and significant and effect on impulse buying discounts have a positif and significanteffect on impulse buying purchases and at Matahari Department Store Pasar Besar Malang. The next researchers are expected to add variables in future studies. Because impulse buying is not only influenced by the store atmosphere and discount variabeles so that it can be even better and can be compared with this study
\end{abstract}

Keywords : Store Atmosphere, Discount and Impulse Buying

\begin{abstract}
Abstrak : Seiring dengan meningkatnya kebutuhan fesyen di Indonesia, fenomena tersebut dimanfaatkan oleh para pelaku bisnis terutama bisnsi ritel. Dari banyak perusahaan retail yang masih berdiri dan bertahan hingga saat ini adalah Matahari Department Store. Matahari Department Store memiliki strategi dalam mempertahankan bisnisnya ialah dengan cara memiliki pengetahuan terhadap perilaku belanja konsumennya. Tujuan penelitian ini adalah untuk mengetahui pengaruh suasana toko dan diskon terhadap pembelian impulsif pada konsumen Matahari Department Store Pasar Besar. Teknik pengambilan sampel yang digunakan adalah Teknik accidental-purposive sampling dengan responden sampel berjumlah 100 orang. Hasil uji analisis regresi linier berganda menemukan bahwa suasana toko berpengaruh positif dan signifikan terhadap pembelian impulsif serta diskon berpengaruh positif dan signifikan terhadap pembelian impulsif pada Matahari Department Store Pasar Besar Malang.
\end{abstract}

Kata Kunci : Sigma Suasana Toko, Diskon dan Pembelian Impulsif. 


\section{PENDAHULUAN}

Perkembangan zaman dan era globalisasi mengubah situasi perekonomian sehingga perusahaan perlu menyesuaikan diri dengan kondisi tersebut. Sistem pengendalian manajemen diperlukan sebagai salah satu strategi pencapaian tujuan jangka pendek dan jangka panjang di organisasi. Menurut Anthony dan Govindrajan (dalam Tjakrawala, 2005), Sistem pengendalian manajemen adalah proses yang memotivasi dan menginspirasi orang-orang dalam suatu organisasi untuk melakukan kegiatan yang mengarah pada pencapaian tujuan organisasi. Artinya sistem pengendalian manajemen dalam pelaksanaannya akan mengarah kepada tujuan yang hendak dicapai perusahaan serta dapat mengarahkan seluruh proses bisnis organisasi sesuai rencana dan tujuan awal organisasi yang telah ditetapkan. BUMN atau badan usaha milik negara, yaitu pelaku ekonomi yang seluruh atau sebagian kekayaannya dikuasai oleh negara. Telkom merupakan perusahaan yang bergerak dibidang jasa teknologi informasi dan komunikasi juga jaringan telekomunikasi di Indonesia. Bentuk perhatian PT. Telkom Indonesia yaitu menciptakan sebuah program tanggung jawab sosial. Tanggung jawab sosial terhadap masyarakat yang dimiliki oleh Telkom melalui paradigma "Telkom ada untuk Indonesia, tumbuh dan berkembang bersama-sama masyarakat Indonesia" yang diyakini Telkom dengan cara meningkatnya kesejahteraan masyarakat maka secara tidak langsung akan berdampak besar dalam keberlangsungan usaha Telkom. Salah satu bentuk program tanggung jawab sosial dari PT. Telkom yaitu dengan menghadirkan Digital Innovation Lounge (DILo).

Digital Innovation Lounge (DILo) merupakan sebuah kamp kreatif yang diinisasi oleh Telkom Indonesia dan Masyarakat Industri Kreatif Teknologi Informasi dan Komunikasi Indonesia (MIKTI). DILo atau Digital Innovation Lounge merupakan wadah atau tempat talenta, start-up dan komunitas bekerja sama dalam membangun mimpi dalam dunia digital melalui program pre-startup development, digital professional talent dan digital community development. DILo merupakan perusahaan yang menawarkan pelatihan kepada UMKM untuk masuk ke dalam platform digital.

DILo dibentuk guna menciptakan dan meningkatkan kualitas serta kuantitas bibit digitalpreneur sekaligus membantu pemberdayaan masyarakat dan komunitas 
yang ada di Indonesia. Menjadi anggota DILo dapat memberikan berbagai keuntungan yaitu dapat menikmati berbagai fasilitas yang disediakan oleh DILo seperti minicafe, coworking, ruang rapat, ruang kelas dan akses internet yang tinggi. Saat ini di Digital Innovation Lounge (DILo) masih terdapat hal yang dapat ditingkatkan terkait dengan pengendalian manajemen. Hal tersebut dapat dilihat dari fenomena yang terjadi yaitu DILo sendiri belum menyadari peran penting pengendalian manajemen sepenuhnya. Terdapat beberapa permasalahan seperti pekerjaan yang tidak langsung diselesaikan, pengawasan operasional yang belum memadai, kegagalan menjalankan perintah hal ini terbukti dari adanya karyawan yang belum bisa menjalankan perintah yang diberikan secara baik sehingga kegiatan pelatihan tidak berjalan baik. Permasalahan tersebut didapatkan saat melakukan observasi dan wawancara kepada seluruh pihak yang terlibat. Selain itu, kurangnya komunikasi antara karyawan dan pimpunan perihal pekerjaan juga berkontribusi terhadap permasalahan tersebut. Maka, perbaikan untuk meningkatkan kualitas kinerja perlu dilakukan.

Peningkatan kualitas dapat menjadi hal yang sulit untuk diidentifikasi dan diukur tanpa kualitas sistem biaya yang efektif. Kualitas dari produk dan jasa tidak hanya fokus pada keluaran namun juga dalam kualitas dari keseluruhan proses bisnis (Love dan Li, 2000). Six sigma merupakan alat yang dapat digunakan dalam pengendalian kualitas di organisasi. Six sigma merupakan metode yang awalnya digunakan di industri manufaktur untuk mengurangi limbah dari proses produksi yang kemudian dikembangkan dan saat ini banyak diimplementasikan dalam berbagai jenis industri termasuk dalam industri jasa (Stewart dan Spencer, 2006; Han et.al. 2008). Six Sigma dianggap sebagai strategi bisnis kuat yang menggunakan metode perbaikan berkelanjutan yang terstruktur dengan baik untuk mengurangi variabilitas proses dan menghilangkan pemborosan dalam proses bisnis menggunakan aplikasi alat dan teknologi yang efektif (Banuelas et.al., 2005). Tujuan utama dari program Six Sigma adalah untuk menciptakan nilai yang lebih tinggi dari produk dan layanan perusahaan di mata pelanggan. Tujuan dari penelitian ini adalah untuk merancang sistem pengendalian manajemen di lingkungan DILo guna meningkatkan kualitas dan meminimalisir kesalahan. Menurut Assuri (2015:139), keputusan pembelian merupakan aktivitas yang 
dipengaruhi oleh suatu kebiasaan dilakukan oleh konsumen saat proses transaksi yang meliputi waktu, tempat dan jumlah pembelian. Menurut Kotler (2014:184), keputusan pembelian ialah keputusna final seseorang dalam proses aktivitas pembelian yang dilakukan oleh individu. Menruut Kotler dan Keller (2016:235), keputusan pembelian terdiri dari beberapa rangkaian aktivitas diantaranya adalah: (1) mengenali kebutuhan (2) pencarian informasi mengenai kebutuhan konsumen yang ingin dipenuhi (3) pengevaluasian alternatif pembelian saat situasi tertentu (4) keputusan pembelian (5) perilaku setelah pembelian.

Menurut Kotler dan Amstrong (2015), terdapat dua faktor yang dapat mempengaruhi keputusan pembelian yang terdiri dari: (1) faktor sikap yang berhubungan dengan pendirian orang lain (2) faktor situasi yang tidak diantisipasi. Menurut Pontoh et al (2017), pembelian impulsif merupakan pembelian produk yang tidak terencana oleh konsumen sebelumnya. Pembelian impulsif dapat terjadi dikarenakan adanya rangsangan yang diterima oleh konsumen yang dalam pengambilan keputusan diputuskan saat itu juga. Menurut Muruganantham dan Bhakat (2013), pembelian impulsif merupakan pembelian langsung tanpa tujuan pembelian pra belanja dengan tujuan untuk memenuhi kebutuhan atau keinginan tertentu. Menurut Utami (2012:68), pembelian impulsif memiliki empat tipe yakni (1) pembelian impulsif murni (2) pembelian impulsif pengingat (3) pembelian impulsif saran dan (4) pembelian impulsif terencana.

Menurut Sari (2018) terdapat indikator pembelian impulsif yakni (1) Spontanity yaitu keinginan yang muncul secara tiba-tiba untuk melakukan suatu pembelian (2) Out of control yaitu ketidakmampuan untuk menolak kepuasan sesaat dan kondisi seseorang yang tidak dapat mentolerasni adanya pemberian pada diri sendiri yang tertunda ataupun terlambat. (3) Psychology conflict yaitu konsumen yang mempertimbangkan manfaat dari kepuasan sesaat dengan konsekuensi jangka panjang. (4) Non cognitive evaluation yakni konsumen akan mengurangi evaluasi kognitif atau intelektual mereka terhadap atribut produk yang akan dibeli. Menurut Berman dan Evans (2012), suasana toko adalah acuan terhadap karakteristik fisik toko yang digunakan untuk mengembangkan citra dan menarik pelanggan. Hussain dan Ali (2015), mengemukakan bahwa cakupan suasana toko ini meliputi bagian Kebersihan (Cleanliness), Musik (Music), Aroma (Scent), Suhu (Temperature), 
Pencahayaan (Lighting), Warna (Color), dan Tampilan atau Tataletak (Display atau Layout)

Menurut Tjiptono (2008:229) diskon atau yang biasa disebut potongan harga merupakan pemotongan harga suatu produk dari harga asal atau harga normalnya. Sedangkan menurut Kotler (2003) Potongan harga atau yang biasa dikenal dengan diskon merupakan sebuah upaya penjual untuk menarik minat beli dari calon Konsumen. Menurut Wahyudi (2017), dimensi dari diskon meliputi (1) Frekuensi diskon, (2) Besaran diskon, dan (3) waktu pemberian diskon.

\section{METODE PENELITIAN}

Penelitian ini dilakukan pada Bulan November 2020 di Matahari Department Store Pasar Besar Malang, Jalan Agus Salim No.10-16, Sukoharjo, Kec. Klojen, Kota Malang, Jawa Timur 65118. Penelitian ini menggunakan pengumpulan data seperti menyebarkan kuisioner dengan skala likert dan wawancara. Populasi penelitian ini adalah seluruh konsumen MatahariDepartment Store Pasar Besar Malang yang tidak diketahui jumlahnya. Sedangkan sampel yang digunakan sebanyak 100 responden dengan teknik sampling yang digunakan ialah teknik accidentalpurposive sampling yaitu responden yang berusia minimal 17 tahun dan pernah melakukan perbelanjaan secara impulsif di Matahari Department Store Pasar Besar Malang.

\section{HASIL PENELITIAN}

\subsection{Uji Validitas}

Pada Uji Reliabilitas seluruh nilai Cronbach's Alpha masing-masing indikator lebih besar dari 0,60. Dengan demikian seluruh item pernyataan dinyatakan reliabel atau handal.

\subsection{Uji Validitas}

Pada Uji Validitas nilai $\alpha$ yang digunakan dalam penelitian ini adalah 0,05 sedangkanr tabel yang dihasilkan adalah 0,1966. Pada tabel uji validitas dapat diketahui bahwa semua nilai $r$ hitung lebih besar daripada $r$ tabel dengan jumlah sampel sebanyak 100 responden. Kemudian apabila dilihat dari perbandingan antara sig.(2-tailed) dan $\alpha$, nilai sig.(2-tailed) lebihkecil dari pada $\alpha$. Dengan demikian seluruh item pernyataan dinyatakan valid.

\subsection{Uji Normalitas}


Tabel 3.1 Uji Normalitas

\begin{tabular}{ccccccc}
\hline & \multicolumn{3}{c}{ Kolmogorov-Smirnova } & \multicolumn{3}{c}{ Shapiro-Wilk } \\
\cline { 2 - 7 } & Statistic & df & Sig. & Statistic & Df & Sig. \\
\hline Suasana Toko (X1) & .086 & 100 & .063 & .983 & 100 & .239 \\
Diskon (X2) & .080 & 100 & .120 & .989 & 100 & .584 \\
Pembelian & .082 & 100 & .098 & .985 & 100 & .315 \\
Impulsif (Y) & & & & & &
\end{tabular}

Sumber : Data Diolah Tahun 2021

Berdasarkan tabel uji normalitas di atas, dapat diketahui bahwa nilai Sig. Kolmogorov-Smirnov semua variabel penelitian lebih besar dari 0,05 $(\alpha)$. Dengan demikian seluruh variabel yang digunakan dalam penelitian berdistribusi normal.

\subsection{Uji Multikolinearitas}

Tabel 3.2 Uji Multikolinearitas

\begin{tabular}{|c|c|c|c|c|c|c|c|c|}
\hline & \multirow{2}{*}{ Model } & \multicolumn{2}{|c|}{$\begin{array}{l}\text { Unstandardized } \\
\text { Coefficients }\end{array}$} & \multirow{2}{*}{$\frac{\begin{array}{c}\text { Standardize } \\
\text { d } \\
\text { Coefficients }\end{array}}{\text { Beta }}$} & \multirow{2}{*}{$\mathbf{T}$} & \multirow{2}{*}{ Sig. } & \multicolumn{2}{|c|}{$\begin{array}{l}\text { Collinearity } \\
\text { Statistics }\end{array}$} \\
\hline & & B & $\begin{array}{l}\text { Std. } \\
\text { Error }\end{array}$ & & & & Tolerance & VIF \\
\hline \multirow[t]{3}{*}{1} & (Constant) & .691 & 1.247 & & .554 & .581 & & \\
\hline & $\begin{array}{c}\text { Suasana Toko } \\
\text { (X1) }\end{array}$ & .479 & .090 & .500 & 5.300 & .000 & .321 & 3.111 \\
\hline & Diskon (X2) & .279 & .067 & .390 & 4.141 & .000 & .321 & 3.111 \\
\hline
\end{tabular}

Sumber : Data Diolah Tahun 2021

Berdasarkan tabel uji multikolinearitas di atas, dapat diketahui bahwa seluruh nilai tolerance pada variabel suasana toko (X1) dan diskon (X2) lebih besar dari 0,1 dan nilai VIF kurang dari 10. Dengan demikian variabel suasana toko (X1) dan diskon (X2) tidak terjadi multikolinearitas.

\subsection{Uji Heteroskedastisitas}

Tabel 3.3 Uji Multikolinearitas

\begin{tabular}{|c|c|c|c|c|c|c|}
\hline & \multirow{2}{*}{ Model } & \multicolumn{2}{|c|}{$\begin{array}{l}\text { Unstandardized } \\
\text { Coefficients }\end{array}$} & \multirow{2}{*}{$\begin{array}{c}\text { Standardiz } \\
\text { ed } \\
\text { Coefficients } \\
\text { Beta }\end{array}$} & \multirow[t]{2}{*}{$\mathbf{T}$} & \multirow[t]{2}{*}{ Sig. } \\
\hline & & B & Std. Error & & & \\
\hline \multirow[t]{3}{*}{1} & (Constant) & -.236 & .881 & & -.267 & .790 \\
\hline & Suasana Toko (X1) & .112 & .064 & .310 & 1.759 & .082 \\
\hline & Diskon (X2) & -.065 & .048 & -.242 & -1.371 & .173 \\
\hline
\end{tabular}

Sumber : Data Diolah Tahun 2021

Berdasarkan tabel Uji Glejser di atas, diketahui bahwa nilai Sig.t variabel suasana toko (X1) dan diskon (X2) lebih besar dari 0,05. Dengan demikian 
menunjukan bahwa antar variabel independent tidak terjadi heteroskedastisitas.

\subsection{Uji Regresi Linear Berganda}

Tabel 3.4 Uji Regresi Linear Berganda

\begin{tabular}{lrlll}
\hline Model & $\mathbf{R}$ & R Square & Adjusted R Square & Std. Error of the Estimate \\
1 & $.850 \mathrm{a}$ & .723 & .717 & 1.276 \\
\hline
\end{tabular}

Sumber : Data Diolah Tahun 2021

Berdasarkan tabel Uji Determinasi ( $R$-Square), dapat diketahui bahwa nilai $R$ Square sebesar 0,723. Artinya sebesar 72,3\% variabel pembelian impulsif (Y) di Matahari DepartmentStore Pasar Besar Malang dijelaskan oleh variabel suasana toko (X1) dan diskon (X2).Sedangkan sisanya yakni 27,7\% dijelaskan oleh variabel-variabel lain yang tidak dipertimbangkan dalam penelitian.

\subsection{Uji Hipotesis ( Uji T)}

Tabel 3.5 Uji Regresi Linear Berganda

\begin{tabular}{|c|c|c|c|c|c|c|c|}
\hline \multirow{2}{*}{ Model } & \multicolumn{2}{|c|}{$\begin{array}{l}\text { Unstandardize } \\
\text { d Coefficients }\end{array}$} & $\begin{array}{l}\text { Standar dized } \\
\text { Coeffici ents }\end{array}$ & \multirow[t]{2}{*}{$\mathbf{t}$} & \multirow[t]{2}{*}{ Sig. } & \multicolumn{2}{|c|}{$\begin{array}{l}\text { Collinearity } \\
\text { Statistics }\end{array}$} \\
\hline & B & Std. Error & rBeta & & & $\begin{array}{l}\text { Toleranc } \\
\text { e }\end{array}$ & VIF \\
\hline \multirow{3}{*}{$\begin{array}{ll}1 & \text { (Constant) } \\
\text { Suasana Toko } \\
\text { (X1) }\end{array}$} & .691 & 1.247 & & .554 & .581 & & \\
\hline & .479 & .090 & .500 & 5.300 & .000 & .321 & 3.111 \\
\hline & .279 & .067 & .390 & 4.141 & .000 & .321 & 3.111 \\
\hline
\end{tabular}

Sumber : Data Diolah Tahun 2021

Nilai t-tabel untuk $\alpha=0,05$ dan df = 97 sebesar 1.98472. Sedangkan nilai thitung variabel suasana toko sebesar 5,300 dengan sig.t sebesar 0,000. Ini menunjukkan bahwa untukvariabel suasana toko nilai t-hitung tidak berada dalam rentang -t-tabel sampai +t-tabel (5,300berada dalam rentang -1.98472 sampai +1.98472$)$, dan sig.t $<\alpha(0,000<0,05)$. Artinya, suasana toko berpengaruh positif dan signifikan terhadappembelian impulsif. Dengan demikian, hipotesis pertama penelitian (h1), yaitu: "suasana toko berpengaruh positif dan signifikan terhadap pembelian impulsif pada matahari department store pasar besar malang", diterima. Dalam hal ini 
pengaruh suasana toko terhadap pembelian impulsif pada matahari department store pasar besar malang berpengaruh positif dan signifikan.

\subsection{Uji Hipotesis ( Uji F)}

Tabel 3.9 Hasil Uji F

\begin{tabular}{|ll|r|r|r|r|r|}
\hline \multirow{2}{*}{ Model } & & Sum ofSquares & $\mathrm{df}$ & \multicolumn{1}{c|}{$\begin{array}{l}\text { Mean } \\
\text { Squar } \\
\text { e }\end{array}$} & F & Sig. \\
\hline 1 & & & & & \\
& Regression & 412.108 & 2 & 206.054 & 126.58 & $.000^{\mathrm{b}}$ \\
& Residual & 157.892 & 97 & 1.628 & 8 & \\
& Total & 570.000 & 99 & & & \\
\hline
\end{tabular}

\section{Sumber: Data Olahan SPSS 16 (data diolah tahun 2021)}

Berdasarkan data dalam tabel Uji F di atas, diketahui bahwa nilai F-hitung sebesar 126,588 dengan sig. sebesar 0,000. Sedangkan nilai F-tabel untuk $\alpha=$ 0,05; df1= 2 dan df2=97sebesar 3,09. Maka nilai F-hitung > F-tabel $(126,588>$ $3,09)$ dan Sig. $<\alpha(0,00<0,05)$. Dengandemikian model regresi yang terbentuk layak dan dapat digunakan untuk memprediksi pembelian impulsif pada Matahari Department Store Pasar Besar Malang.

\section{PEMBAHASAN}

\subsection{Suasana Toko dan Pembelian Impulsif}

Berdasarkan deskripsi jawaban responden untuk variabel suasana toko (X1), kondisi toko Matahari Department Store Pasar Besar Malang sebenarnya dapat tingkatkan kembali agardapat meningkatkan pembelian impulsif lebih tinggi. Adapun cara dalam meningkatakan suasana toko dengan tujuan untuk meningkatkan pembelian impulsif adalah dengan selalu memperhatikan kebersihan toko yakni mengerahkan tenaga kebersihan untuk membersihkan lantai dan rak toko pada saat jam buka dan jam tutup toko. Kemudian pemilihan musik toko juga berpengaruh untuk meningkatkan emosional konsumen. berikutnya dalam meningkatkanpembelian impulsif melalui suasana toko ialah aroma dengan memberikan pengharum ruangandi dekat pendingin ruangan. Kemudian temperatur atau suhu ruangan harus tetap terjaga dengan menyediakan air conditioner (AC) disetiap sudut toko untuk menjaga temperatur tetapstabil. Kemudian Penciptaan cahaya toko harus diperhatikan guna mempermudah akses konsumen untuk memilih produk yang ditawarkan. Hal yang tidak kalah penting dalampenciptaan suasana toko ialah pemilihan 
warna yang harus sesuai dengan kategori produk yang ditawarkan serta penataan produk yang harus memudahkan konsumen untuk memilih produk yang diinginkan.

\subsection{Diskon dan Pembelian Impulsif}

Berdasarkan deskripsi jawaban responden untuk variabel diskon (X2), Semakin tinggi diskon maka semakin tinggi pula pembelian impulsif pada Matahari Department Store Pasar Besar Malang. Hasil dari pengamatan di lapangan dapat diketahui bahwa sebagian besar responden yang ditemui di lapangan dalam penelitian pada Matahari Department Store Pasar Besar Malang yang didominasi oleh responden yang berusia 17 hingga 25 tahun dengan income kurang dari Rp 2,9 juta mereka cenderung untuk membeli barang belanjaan pada saat ada penawaran khusus yakni diskon. Hal ini juga sesuai dengan dominasi status responden yang sebagian besar didominasi oleh pelajar atau mahasiswa, yang notabene mereka ialah anak kos yang memerlukan penghematan untuk biaya sehari-hari. Mereka juga akan membeli produk yang sesuai dengan yang diinginkan dari pada yang dibutuhkan tanpa berpikir panjang, apalagiproduk yang mereka inginkan terdapat penawaran khusus. Kemudian sebagian besar dari responden ialah kaum perempuan. Biasanya kaum perempuan cenderung lebih mudah tertarik dengan adanya penawaran khusus seperti diskon sehingga mereka akan membeli produk tanpa berpikir panjang. Sehingga diskon berpengaruh positif dan signifikan terhadap pembelian impulsive di Matahari Departemen Store Pasar Besar Malang. Diskon memberikan daya tarik tersendiri terhadap keputusan pembelian impulsif yang dilakukan oleh konsumen yang menjadiresponden dikarenakan diskon selalu memberikan harga yang jauh lebih rendah darpida harganormal yang tertera pada produk.

\section{KESIMPULAN}

Berdasarkan hasil analisis dan pembahasan tentang pengaruh suasana toko dan diskonterhadap pembelian impulsif pada Matahari Department Store Pasar Besar Malang, dapat ditarik kesimpulan antara lain : Suasana toko berpengaruh positif dan signifikan terhadap pembelian impulsif serta Diskon berpengaruh positif dan signifikan pada Matahari DepartmentStore Pasar Besar Malang. Hal ini menunjukan 
bahwa indikator-indikator dari masing-masing variabel suasana toko dan variabel diskon memengaruhi responden dalam melakukan pembelian impulsif.

\section{REFERENSI}

Abeng,Tanri. 2000. Managing atau Chaos, Pustaka Sinar Harapan. Ali, Hasan. 2008. Marketing. Yogyakarta. Media Pressindo.

Amsani,Putri Deacitra Dan Sudharto P.Hadi. 2016. Pengaruh Discount dan Store Atmosphere Terhadap perilaku impulse buying (Studi Kasus Pada Konsumen Lottermart Wholesale Semarang). Semarang : UNDIP

Arif, Isnaini, 2005. Model dan Strategi Pemasaran. Mataram : NTP Press Mataram. Badan Ekonomi Kreatif. 2017.Dalam www.bekraf.go.id.Diakses pada 15 Juli 2020 Badan Pusat Statistik. 2015. Dalam www.bps.go.id. Diakses pada 15 Juli 2020

Badan Pusat Statistik Kota Malang. 2020. Dalam www.malangkota.bps.go.id. Diakses pada 7 Oktober 2020

Berman \& Evan. 1992. Retail Management: A Strategic Approach. United State of American:Pearson Education,. Inc.

CEIC Data.2020. Dalam www.ceicdata.com. Diakses pada 15 Juli 2020.

Charles W. Lamb, Joseph F. Hair, Carl McDaniel. 2001. Pemasaran, Edisi Pertama. Salemba: Empat. Jakarta

CNBC. 2019. Dalam www.cnbcindonesia.com Diakses pada 29 Oktober 2020.

Dalihade, Meigie Putri., James Massie Dan Maria Tielung. 2017. Pengaruh Potongan Harga Dan Store Atmosphere Terhadap Impulse Buying Pada Matahari Department Store Mega Mall Manado. Jurnal EMBA. Vol.5,No.3

Davis, F. D. 1989. Perceived Usefulness, Perceived Ease of Use, and User.Acceptance of Information Technology. MIS Quarterly.

Deddy Rahman Saputra, Nur Hidayati Dan M. Ridwan Basalamah. 2019. Pengaruh Marchandise, Store atmosphere dan Price Discount Terhadap Impulse buying Studi Pada Konsumen Ramayana Department Store Malang. Malang : UB Press

Ghozali, Imam. 2011. Aplikasi Analisis Multivariate Dengan Program SPSS. Semarang: Badan Penerbit Universitas Diponegoro

Hawkins \& Mothersbaugh. 2013. Consumer Behavior: Building Marketing Strategy. New York: The Mc Graw-Hill Companies, Inc.

Hendraningrum dan M. Edy Susilo. 2020. Fashion dan Gaya Hidup : Identitas dan Komunikasi.

Jurnal Ilmu Komunikasi.Vol 6, No. 2. Yogyakarta: UPN Veteran Yogyakarta.

Hussain, Riaz dan Mazhar Ali. 2015. Effect of Store atmosphere on Consumer Purchase Intention. International Journal of Marketing Studies. Vol. 7, No. 2; 2015, ISSN 1918 719X E-ISSN 1918-7203, Published by Canadian Center of Science and Education.

Kotler, Philip.2003. Manajemen Pemasaran. Edisi kesebelas. Jakarta: Indeks kelompok Gramedia.

Kotler, P.2004. Manajemen Pemasaran. Edisi Millennium. Jakarta:PT. Prenhallinda. Jakarta Kotler, Philip. 2005. Manajemen Pemasaran. Jilid 1 dan 2. Jakarta : PT Indeks.

Kotler, Philip dan Gary Amstrong. 2008. Prinsip-prinsip Pemasaran. Jilid 1. Jakarta 
: Erlangga.

Kotler, Philip dan Kevin Lane Keller. 2008. Manajemen Pemasaran. Jilid 1.

Jakarta : Erlangga.

Kotler, K.2009. Manajemen Pemasaran 1.Edisi ketiga belas. Jakarta: Erlangga

Kotler dan Keller. 2012. Manajemen Pemasaran. Edisi 12. Jakarta: Erlangga

Kotler, Philip dan Amstrong, Gary.2014. Principles of Marketing. 12th. Edition. Jilid 1 Terjemahan Bob Sabran. Jakarta : Erlangga.

Kotler, Philip and Gary Amstrong. 2016. Prinsip-prinsip Pemasaran. Edisi 13. Jilid 1.Jakarta:Erlangga

Kurniawati, Devi dan Restuti, Sri. 2014. Pengaruh Sales Promotion Dan Store Atmosphere Terhadap Shopping Emotion Dan Impulse buying Pada Giant Pekanbaru. Jurnal Tepak Manajemen Bisnis. Vol. VI, No. 3.

Lamb , Charles W. , Joseph F. Hair dan Carl McDaniel. 2001. Pemasaran. Edisi Pertama. Jakarta : Salemba Empat.

Levy \& Weitz, 2001. Retailing Management.4th edition. New York: Mc.GrawHill. Martono, Nanang. 2010. Metode Penelitian Kuantitatif. Jakarta : Rajawali Pers. Nawawi, M.Iqbal., Muhammad Manasur dan M. Khoirul. 2019. Pengaruh Discount, Merchandising, Dan Store atmosphere Terhadap Impulse buying Pada Konsumen Swalayan KUD Pakis. Malang : UNISMA

Matahari.2020. Dalam www.matahari.com. Diakses pada 7 September 2020.

Mowen, John C dan Michael Minor. 2001. Perilaku Konsumen. Jilid 1 Edisi Kelima. Jakarta: Erlangga.

Nawari. 2010. Analisis Regresi dengan MS Excel 2007 dan SPSS 17. Jakarta : PT. Elex Media Komputindo

Pontoh. M.E, dkk. (2017). Pengaruh Display Produk Dan Store Atmosphere Terhadap Impulse Buying Pada Konsumen Matahari Department Store Mega Mall Manado. Jurnal EMBA. Vol 5. No.2. Hal 1823-1933.

Ridhotullah,Subekti dan Juhar, Muhammad.2015. Pengantar Manajemen. Jakarta : Prestasi Pustaka Jakarta

Sancaya.2020. Dalam www.detik.com . Diakses pada Diakses pada 15 Juli 2020

Sari, Andini Kartika. 2018. Pengaruh Discount, Brand Image dan Store Atmosphere Terhadap Impulse Buying. Makassar : UMS

Setiadi, Nugroho J. 2010. Perilaku Konsumen. Cetakan 4. Edisi Revisi. Jakarta : Kencana. Setiawan. 2007. Analisis Pengaruh Pembelian Spontan. Jakarta : Salemba Empat.

Singarimbun, M. 2006. Metode penelitian Survei. Jakarta. LP3ES. Sudaryono. 2017. Metodologi Penelitian. Jakarta: PT Raja Grafindo Persada.

Susanta.2007. Perilaku Berbelanja Konsumen Dewasa ini. Edisi Khusus. Jakarta : Erlangga Sugiyono. 2015. Metode Penelitian Kombinasi (Mix Methods). Bandung: Alfabeta

Sutisna. 2002. Perilaku Konsumen \& Komunikasi Pemasaran. Bandung: PT. Remaja. 